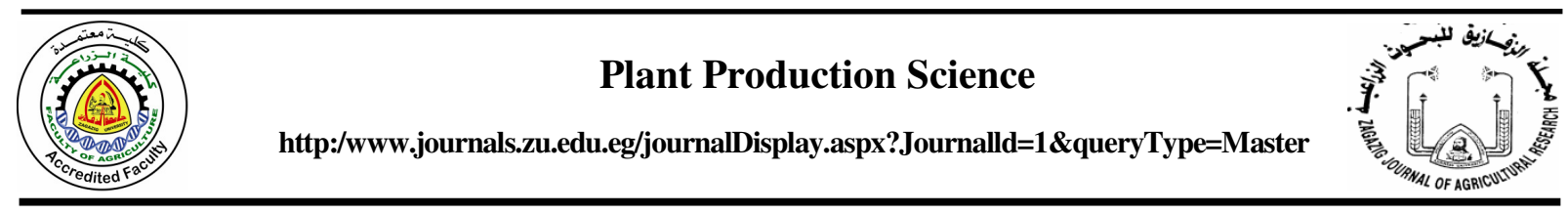

\title{
EVALUATION OF SOME NEW AND OLD FABA BEAN CULTIVARS (Vicia faba L.) FOR EARLINESS, YIELD, YIELD ATTRIBUTES AND QUALITY CHARACTERS
}

\author{
Naglaa Qabil $^{1 *}$, A.A. Helal ${ }^{2}$ and Rasha Y.S. Abd El-Khalek ${ }^{3}$ \\ 1. Agron. Dept., Fac. Agric., Zagazig Univ., Egypt \\ 2. Genet. Res. Dept., Field Crops Res. Inst., ARC, Bahteem, Giza, Egypt \\ 3. Seed Tech. Res. Dept., Field Crops Res. Inst., ARC, Giza, Egypt
}

Received: 25/02/2018; Accepted: 17/04/2018

\begin{abstract}
The present study was carried out at Genetic Resources Department, Bahteem, Egypt, during 2014/2015 and 2015 /2016 seasons, to evaluate five new faba bean cultivars (Misr 3, Sakha 4, Wadi1, Nubaria 1and Nubaria 3) as well as five old ones (Giza 2, Giza 3, Giza 40, Giza 429 and Giza 843) for earliness, yield, yield attributes and quality characteristics through mean performance, correlation coefficient, path coefficient and molecular markers of RAPD-PCR analysis. The experimental design was a randomized complete block design in four replications. Results indicated highly significant differences among the ten faba bean cultivars for earliness characters (days to first flower, days to $50 \%$ flowering and days to fruiting), yield and its attributes (plant height, number of branches/plant, number of fruiting nodes/plant, pod length, number of pods/node, number of pods/plant, number of seeds/pod, number of seeds/plant, 100- seed weight and seed yield/ plant) as well as quality characters (protein and carbohydrate contents) in the two seasons. The new cultivars were earlier than the old once during the two seasons. The new faba bean cultivar Nubaria 1 gave the highest productivity however Sakha 4 recorded the highest value of protein and carbohydrate contents in the two seasons. Seed yield/plant appeared positive and significant correlation with each of pod length, number of pods/plant, number of seeds/ pod, number of seeds/plant and 100-seed weight during the two seasons. Whereas, negative and significant correlation was detected between seed yield/plant and each of plant height and number of fruiting nodes/plant in both seasons. Path coefficient analysis showed that number of seeds/plant followed by 100 -seed weight had the highest direct effect on seed yield/plant during the two seasons. Five primers were used for RAPD analysis to determine genetic variability among the ten cultivars of faba bean, and produced 32 bands, 21 of them were polymorphic with $65.6 \%$ polymorphism. Four positive bands markers were recorded in faba bean cultivar Giza 3 in two primes (C06 and C19), and two positive band markers in faba bean cultivar Giza 40 in the two primers (B09 and C19). While, one negative band marker in Giza 429 and one positive marker in Giza 843 were generated by primer (C19).
\end{abstract}

Key words: Faba bean, mean performance, correlation coefficient, path coefficient, molecular markers RAPD-PCR.

\section{INTRODUCTION}

Faba bean (Vicia faba L.) is one of the main pulse crops grown for seed in Egypt. It is a diploid $(2 \mathrm{n}=12)$, self pollinated annual plant. It is widely considered as a good source of protein,

\footnotetext{
Corresponding author: Tel. : +201117624082

E-mail address: naglaaqabil82@yahoo.com
}

starch, cellulose and minerals for humans in developing countries and animals in industrialized countries (Haciseferogullari $\boldsymbol{e t}$ al., 2003). In addition, faba bean is one of the most efficient fixers of the atmospheric nitrogen and hence, can contribute to sustain or enhance 
total soil nitrogen fertility through biological N2- fixation (Lindemann and Glover, 2003).

Faba bean (Vicia faba L.) is the major legume crop among pulses in Egypt, the cultivated area devoted to faba bean represented 34314 ha, and the corresponding annual national production increased up to 119104 ton with an average seed yield of 9.0 ardab/fad., (FAO, 2018).

The possibility of increasing the cultivated area is limited. Hence increasing productivity through developing new high yielding varieties prerequisite. Various attributes such as duration of flowering, number of pods, number of seeds and seed size could be used as selection criteria for the improvement of yield (El-Hady et al., 1998).

A successful selection depends upon the information on the genetic variability and correlation of morpho-agronomic characters with seed yield. Sharifi (2014) and Kumar et al. (2017) recorded significant positive correlation of seed yield with each of pod length, number of seeds/pod and 100- seed weight. Moreover, path analysis is regarded helpful for plant breeders as it partitions genotypic association analysis into direct and indirect components for identifying the most important characters could be used as selection criteria in faba bean breeding programs.

The use of Random Amplified Polymorphic DNA (RAPD) technique offers a simple, fast, efficient and inexpensive method (BaheerSalimia et al., 2012). Furthermore, it does not need knowledge of marker sequence and can produce abundant polymorphic DNA fragments (Kocsis et al., 2005; Achtak et al., 2009). Therefore, RAPD is a powerful and accurate tool for analyzing the genetic relatedness and diversity in many species. The DNA markers like RAPD, ISSR. AFLP and SSR were extensively used in assessing genetic diversity in faba bean (Wang et al., 2012). The analysis of faba been cultivars leads to collection of information about the genetic diversity at the genome level. The RAPD profile analysis can be useful to the selection of cultivar containing good information and properties in faba bean improvement program (Tahir, 2015).
The objectives of the present study were to evaluate five new faba bean cultivars in comparison to five old faba bean cultivars for earliness, yield, its attributes and quality characters through mean performance. Also, identify the most important characters related to seed yield through correlation and path coefficient analysis as well as finding molecular marker be used PCR-based RAPD (Random Amplified Polymorphic DNA) to determine genetic variability among faba bean cultivars.

\section{MATERIALS AND METHODS}

The present investigation was conducted during the two winter growing seasons: 2014/2015 and 2015/2016 at Genetic Resources Department, Bahteem, Egypt. Five new faba bean cultivars (Misr 3, Sakha 4, Wadi 1, Nubaria 1 and Nubaria 3) as well as five old ones (Giza 2, Giza 3, Giza 40, Giza 429 and Giza 843) have been employed as the materials in this investigation. The origin and pedigree of the studied faba bean cultivars are presented in Table 1.

In 2014/2015 and 2015/2016 seasons, the experimental trials were conducted included ten cultivars using a randomized complete block design with 4 replications. Each plot consisted of 3 rows with $3 \mathrm{~m}$ long and distance between rows was $60 \mathrm{~cm}$ with single seeded hills, $20 \mathrm{~cm}$ a part. Cultural procedures were applied as recommended.

The studied traits were recorded on ten guarded plants for each cultivar and the following characters were studied (days to first flower (day), days to $50 \%$ flowering (day), days to fruiting (day), plant height $(\mathrm{cm})$, number of branches/plant, number of fruiting nodes/plant, pod length $(\mathrm{cm})$, number of pods/node, number of pods/plant, number of seeds /pod, number of seeds/plant, 100-seed weight $(\mathrm{g})$, seed yield/ plant (g.), protein content (\%) and carbohydrate content \%).

Statistical analysis using ANOVA and simple correlation of the collected data were subjected to Duncan's multiple range test (Duncan, 1955) at the 5\% level and the mean values obtained were compared by the Least Significant Range test $\left(\mathrm{LSR}_{\mathrm{D}}\right)$. 
Zagazig J. Agric. Res., Vol. 45 No. (3) 2018

Table 1. Origin and pedigree of the ten Egyptian faba bean cultivars used in this study

\begin{tabular}{lll}
\hline Cultivar & Origin & Pedigree \\
\hline Misr 3 & Egypt & 667x (Cairo 241x Giza 461) \\
Sakha 4 & Egypt & Sakha 1 x Giza 3 \\
Wadi 1 & Egypt & Rena Blanka x Triple white \\
Nubaria 1 & Egypt & Selection in Rena Blanka \\
Nubaria 3 & Egypt & Selection in Ahnasiaz \\
Giza 2 & Egypt & Individual plant selection from local variety \\
Giza 3 & Egypt & Giza 1 x New Accession 29 \\
Giza 40 & Egypt & Individual plant selection from Repaya 40 \\
Giza 429 & Egypt & Individual plant selection from Giza 402 \\
Giza 843 & Egypt & 561/2076/85 Sakha x461/845/83 \\
\hline
\end{tabular}

The contribution of yield components in seed yield in these group of genotypes are estimated using path coefficient analysis according to Dewy and Lu (1959).

For genomic DNA isolation, seeds of each faba bean cultivar were germinated and grown to the four-leaf stage. The seedlings were used for DNA extraction by DNeasy plant minikit (Quigen Inc., Cat.no.69104, and USA). The DNA concentration of the final samples was measured by ultraviolet (UV) spectrophotometer at $260 \mathrm{~nm}$. The integrity of the DNA was checked by electrophoresis in a $1.2 \%$ agarose gel in TAE buffer.

Five RAPD primers were used to evaluate the ten faba been cultivars and are shown in Table 2 .

DNA amplification was carried out in PCR (Polymerase Chain Reaction) tubes containing $25 \mu l$ reaction mixture, having $1 \mu l$ template DNA, $1 \mu \mathrm{l}$ RAPD primer, $15 \mu \mathrm{l}$ of $\mathrm{dd}_{2} \mathrm{H}_{2} \mathrm{O}$ and 7 $\mu$ PCR mix. Amplification was carried out in a PTC-200 thermal cycler (MJ Research, Watertown, USA) programmed as follows: Denaturation, $94^{\circ} \mathrm{C}$ for 2 minutes, then for 40 cycles. Each cycle consisted of 1 minute at $94^{\circ} \mathrm{C}, 1$ minute at $37^{\circ} \mathrm{C}, 2$ minutes and 30 second at $72^{\circ} \mathrm{C}$, followed by a final extension time of 12 minutes at $72^{\circ} \mathrm{C}$ and $4^{\circ} \mathrm{C}$ (infinitive).

Gel electrophoresis was applied according to Sambrook et al. (1989). The run was performed for one hour at 80 volt in pharmacia submarine $(20 \times 20 \mathrm{~cm})$. Bands were detected on UV trans illuminator and photographed by Gel documentation 2000, Bio- Rad. Fragment sizes of RAPD were estimated from the gel by comparison with the $100+1.5 \mathrm{~kb}$ ladder marker. The bands were recorded as either present or absent into a database of "+" and "_"”.

The data of PCR systems were analyzed to detect the similarity matrices using Gel/works 1D- advanced software UVP-England program. The relationships among different ten cultivars as revealed by dendrograms resolved using SPSS Windows (Version 16) program, were estimated and possible molecular markers for different qualitative and quantitative characteristics were detected for subsequent linkage and genome analysis.

\section{RESULTS AND DISCUSSION}

\section{Mean Performance}

\section{Earliness characters}

Mean performance of earliness characters i.e. days to first flower, days to $50 \%$ flowering and days to fruiting for the ten faba bean cultivars during the two seasons are presented in Table 3. It is interest to note that, highly significant differences were recorded among the ten faba bean cultivars (old and new cultivars) for earliness characters during the first and second seasons. 
Table 2. Names and sequences of the used RAPD primers that were screened

\begin{tabular}{ll}
\hline Primer name & Nucleotide sequences \\
\hline B09 & 5'-TGGGGGACTC-3' \\
C06 & 5'- GAACGGACTC-3' \\
C08 & 5'- TGGACCGGTG-3' \\
C19 & 5'- GTTGCCAGCC-3', \\
D13 & 5'- GGGGTGACGA-3' \\
\hline
\end{tabular}

Table 3. Mean performance of the ten faba bean cultivars for earliness, yield, its attributes and quality characters during the two seasons of 2014 / 2015 and 2015 / 2016

\begin{tabular}{|c|c|c|c|c|c|c|c|c|c|c|}
\hline \multirow[t]{2}{*}{ Genotype } & \multicolumn{2}{|c|}{$\begin{array}{l}\text { Days to first } \\
\text { flower (day) }\end{array}$} & \multicolumn{2}{|c|}{$\begin{array}{c}\text { Days to } 50 \% \text { flowering } \\
(\text { day })\end{array}$} & \multicolumn{2}{|c|}{$\begin{array}{c}\text { Days to } \\
\text { fruiting (day) }\end{array}$} & \multicolumn{2}{|c|}{$\begin{array}{c}\text { Plant height } \\
(\mathrm{cm})\end{array}$} & \multicolumn{2}{|c|}{$\begin{array}{c}\text { Number of branches/ } \\
\text { plant }\end{array}$} \\
\hline & $2014 / 2015$ & $2015 / 2016$ & $2014 / 2015$ & $2015 / 2016$ & $2014 / 2015$ & $2015 / 2016$ & $2014 / 2015$ & $2015 / 2016$ & $2014 / 2015$ & $2015 / 2016$ \\
\hline Misr 3 & $47 d$ & $45 \mathrm{e}$ & $51 \mathrm{~cd}$ & $50 d$ & $63 \mathrm{~cd}$ & $61 d$ & $108.8 \mathrm{c}$ & $108.92 \mathrm{c}$ & $4.07 \mathrm{ab}$ & $4.07 \mathrm{ab}$ \\
\hline Sakha 4 & $44 \mathrm{e}$ & 46de & $50 \mathrm{~d}$ & $50 \mathrm{~d}$ & $60 \mathrm{e}$ & $60 d$ & $111.32 \mathrm{c}$ & $116.32 b$ & $25 \mathrm{~cd}$ & $50 \mathrm{cb}$ \\
\hline Wadi 1 & $35 \mathrm{~g}$ & $36 \mathrm{~g}$ & $42 \mathrm{f}$ & $40 \mathrm{f}$ & $55 \mathrm{f}$ & $56 \mathrm{e}$ & $108.75 c$ & $102.50 \mathrm{de}$ & $3.50 b c$ & $3.75 b$ \\
\hline Nubaria 1 & $49 \mathrm{~cd}$ & $48 \mathrm{~cd}$ & $53 c$ & $53 c$ & $64 c$ & $64 c$ & $88.75 \mathrm{e}$ & $91.37 f$ & $2.75 \mathrm{~cd}$ & $2.85 \mathrm{~cd}$ \\
\hline Nubaria 3 & $40 \mathrm{f}$ & $40 \mathrm{f}$ & $45 \mathrm{e}$ & $45 \mathrm{e}$ & $62 d$ & $61 d$ & $112.50 \mathrm{c}$ & $110.00 \mathrm{c}$ & $2.75 \mathrm{~cd}$ & $2.85 \mathrm{~cd}$ \\
\hline Giza 2 & $51 b c$ & $50 \mathrm{bc}$ & $56 b$ & $56 b$ & $69 a b$ & $68 b$ & $126.27 \mathrm{a}$ & $127.50 \mathrm{a}$ & $3.50 \mathrm{bc}$ & $3.75 b$ \\
\hline Giza 3 & $55 \mathrm{a}$ & $55 \mathrm{a}$ & $59 a$ & $61 \mathrm{a}$ & $70 \mathrm{a}$ & $70 a$ & $108.75 \mathrm{c}$ & $106.00 \mathrm{~cd}$ & $3.25 \mathrm{~cd}$ & $3.50 b c$ \\
\hline Giza 40 & $51 b c$ & $50 \mathrm{bc}$ & $56 b$ & $56 b$ & $70 \mathrm{a}$ & $69 a b$ & $95.00 \mathrm{~d}$ & $98.75 \mathrm{e}$ & $3.25 \mathrm{~cd}$ & $3.50 \mathrm{bc}$ \\
\hline Giza 429 & $50 c$ & $51 b$ & $56 b$ & $55 \mathrm{bc}$ & $69 a b$ & $70 \mathrm{a}$ & $118.85 b$ & $117.60 \mathrm{~b}$ & $4.65 a$ & $4.82 \mathrm{a}$ \\
\hline Giza 843 & $53 a b$ & $55 a$ & $61 a$ & $62 \mathrm{a}$ & $68 b$ & $70 a$ & $95.00 \mathrm{~d}$ & $98.75 \mathrm{e}$ & $2.50 \mathrm{~d}$ & $2.50 \mathrm{~d}$ \\
\hline F. test & $* *$ & $* *$ & $* *$ & $* *$ & $* *$ & $* *$ & $* *$ & $* *$ & $* *$ & $* *$ \\
\hline \multirow[t]{2}{*}{ Genotype } & \multicolumn{2}{|c|}{$\begin{array}{c}\text { Number of fruiting } \\
\text { nodes/ plant }\end{array}$} & \multicolumn{2}{|c|}{$\begin{array}{c}\text { Pod length } \\
(\mathrm{cm})\end{array}$} & \multicolumn{2}{|c|}{$\begin{array}{l}\text { Number of } \\
\text { pods / node }\end{array}$} & \multicolumn{2}{|c|}{$\begin{array}{l}\text { Number of } \\
\text { pods / plant }\end{array}$} & \multicolumn{2}{|c|}{$\begin{array}{c}\text { Number of } \\
\text { seeds pod }\end{array}$} \\
\hline & $2014 / 2015$ & $2015 / 2016$ & $2014 / 2015$ & $2015 / 2016$ & $2014 / 2015$ & $2015 / 2016$ & $2014 / 2015$ & $2015 / 2016$ & $2014 / 2015$ & $2015 / 2016$ \\
\hline Misr 3 & $10.75 \mathrm{de}$ & $10.25 c$ & $9.60 b c$ & $9.25 b c$ & $1.50 \mathrm{bc}$ & $2.00 \mathrm{bc}$ & $17.50 \mathrm{bc}$ & $17.25 b c$ & cde & cde \\
\hline Sakha 4 & $12.25 \mathrm{~cd}$ & $14.00 \mathrm{a}$ & $9.60 \mathrm{bc}$ & $9.25 b c$ & $2.00 \mathrm{ab}$ & $2.65 a$ & $14.62 \mathrm{cde}$ & $14.40 \mathrm{cde}$ & $4.07 \mathrm{bc}$ & $4.07 \mathrm{bc}$ \\
\hline Wadi 1 & $9.25 \mathrm{ef}$ & $9.25 \mathrm{c}$ & $9.00 \mathrm{~cd}$ & $9.90 \mathrm{~b}$ & $1.07 \mathrm{c}$ & $1.15 \mathrm{~d}$ & $10.50 \mathrm{f}$ & $12.25 \mathrm{e}$ & $3.75 \mathrm{~cd}$ & $3.75 \mathrm{~cd}$ \\
\hline Nubaria 1 & $9.00 \mathrm{f}$ & $9.25 \mathrm{c}$ & $17 \mathrm{ab}$ & $11.15 \mathrm{a}$ & $1.50 \mathrm{bc}$ & $1.50 \mathrm{~cd}$ & $17.25 \mathrm{bc}$ & $.50 \mathrm{bc}$ & $7 \mathrm{a}$ & $4.60 \mathrm{ab}$ \\
\hline Nubaria 3 & $16.00 \mathrm{a}$ & $14.75 \mathrm{a}$ & $9.32 \mathrm{bc}$ & $8.25 \mathrm{de}$ & $2.00 \mathrm{ab}$ & $1.50 \mathrm{~cd}$ & 13.75def & $13.75 \mathrm{de}$ & $3.00 \mathrm{e}$ & $3.00 \mathrm{e}$ \\
\hline Giza 2 & $17.50 \mathrm{a}$ & $14.50 \mathrm{a}$ & $75 \mathrm{~cd}$ & $8.82 \mathrm{~cd}$ & $2.60 \mathrm{a}$ & $2.32 \mathrm{ab}$ & $21.65 a$ & $.62 a$ & Ocde & $3.25 \mathrm{de}$ \\
\hline Giza 3 & $12.50 \mathrm{bc}$ & $14.25 \mathrm{a}$ & $9.60 \mathrm{bc}$ & $9.50 \mathrm{bc}$ & $1.82 b$ & $2.00 \mathrm{bc}$ & $12.32 \mathrm{ef}$ & $12.25 \mathrm{e}$ & $3.25 \mathrm{de}$ & $3.25 \mathrm{de}$ \\
\hline Giza 40 & $14.00 \mathrm{~b}$ & $14.00 \mathrm{a}$ & $10.75 a$ & $8.82 \mathrm{~cd}$ & $1.50 \mathrm{bc}$ & $1.50 \mathrm{~cd}$ & $18.85 \mathrm{ab}$ & $18.00 \mathrm{ab}$ & $4.50 \mathrm{~b}$ & $4.87 \mathrm{a}$ \\
\hline Giza 429 & $17.50 \mathrm{a}$ & $14.50 \mathrm{a}$ & $8.25 \mathrm{~d}$ & $8.25 \mathrm{de}$ & $1.50 \mathrm{bc}$ & $1.50 \mathrm{~cd}$ & $16.50 \mathrm{bcd}$ & $15.75 \mathrm{bcd}$ & $3.00 \mathrm{e}$ & $3.00 \mathrm{e}$ \\
\hline Giza 843 & $9.25 \mathrm{ef}$ & $12.00 \mathrm{~b}$ & $9.32 b c$ & $7.75 \mathrm{e}$ & $1.50 \mathrm{bc}$ & $2.00 \mathrm{bc}$ & $16.00 \mathrm{bcd}$ & $15.50 \mathrm{bcd}$ & $3.25 \mathrm{de}$ & $3.50 \mathrm{cde}$ \\
\hline F. test & ** & $* *$ & $* *$ & $* *$ & $* *$ & $* *$ & $* *$ & $* *$ & $* *$ & ** \\
\hline \multirow[t]{2}{*}{ Genotype } & \multicolumn{2}{|c|}{$\begin{array}{c}\text { Number of } \\
\text { seeds / plant }\end{array}$} & \multicolumn{2}{|c|}{$\begin{array}{c}\text { 100- seed } \\
\text { weight (g.) }\end{array}$} & \multicolumn{2}{|c|}{ Seed yield / plant (g.) } & \multicolumn{2}{|c|}{$\begin{array}{c}\begin{array}{c}\text { Protein } \\
\text { content }(\%)\end{array} \\
\end{array}$} & \multicolumn{2}{|c|}{$\begin{array}{c}\text { Carbohydrate conten } \\
(\%)\end{array}$} \\
\hline & $2014 / 2015$ & $2015 / 2016$ & $2014 / 2015$ & $2015 / 2016$ & $52014 / 2015$ & $2015 / 2016$ & $2014 / 2015$ & $2015 / 2016$ & $2014 / 2015$ & $2015 / 2016$ \\
\hline Misr 3 & $44.75 c$ & $41.25 \mathrm{f}$ & $96.70 a$ & $97.45 a$ & $43.20 b$ & $41.87 c$ & $24.82 b$ & $24.19 \mathrm{~d}$ & $63.45 b$ & $63.22 b$ \\
\hline Sakha 4 & $42.95 \mathrm{c}$ & $41.50 f$ & $92.65 \mathrm{a}$ & $94.02 \mathrm{ab}$ & $38.02 \mathrm{~cd}$ & $39.02 d$ & $27.55 \mathrm{a}$ & $28.26 \mathrm{a}$ & $65.51 \mathrm{a}$ & $65.15 \mathrm{a}$ \\
\hline Wadi 1 & $34.75 d$ & $43.12 f$ & $86.22 b$ & $88.77 \mathrm{c}$ & $29.95 \mathrm{e}$ & $38.20 \mathrm{~d}$ & $23.88 \mathrm{e}$ & $23.57 \mathrm{e}$ & $54.45 \mathrm{~g}$ & $53.03 \mathrm{f}$ \\
\hline Nubaria 1 & $71.95 \mathrm{a}$ & $61.75 \mathrm{c}$ & $94.72 \mathrm{a}$ & $91.70 \mathrm{bc}$ & $70.42 \mathrm{a}$ & $57.10 \mathrm{a}$ & $24.35 \mathrm{~cd}$ & $24.65 c$ & $58.32 \mathrm{e}$ & $57.15 \mathrm{e}$ \\
\hline Nubaria 3 & $42.50 \mathrm{c}$ & $46.50 \mathrm{e}$ & $58.60 \mathrm{f}$ & $62.55 f$ & $27.30 \mathrm{e}$ & $28.05 \mathrm{e}$ & $24.51 \mathrm{bcd}$ & $24.24 d$ & $56.98 \mathrm{f}$ & $56.92 \mathrm{e}$ \\
\hline Giza 2 & $59.82 b$ & $70.25 b$ & $60.00 \mathrm{f}$ & $60.22 f$ & $35.85 d$ & $42.30 \mathrm{c}$ & $22.81 \mathrm{f}$ & $22.62 f$ & $52.77 \mathrm{~h}$ & $52.77 \mathrm{f}$ \\
\hline Giza 3 & $37.30 \mathrm{~d}$ & $41.00 \mathrm{f}$ & $75.65 d$ & $74.37 \mathrm{de}$ & $28.02 \mathrm{e}$ & $30.57 \mathrm{e}$ & $24.71 b c$ & $25.175 b$ & $60.88 \mathrm{c}$ & $60.55 c$ \\
\hline Giza 40 & $57.25 b$ & $74.87 \mathrm{a}$ & $70.42 \mathrm{e}$ & $70.00 \mathrm{e}$ & $40.30 \mathrm{bc}$ & $52.32 \mathrm{~b}$ & $24.22 \mathrm{de}$ & $25.08 \mathrm{~b}$ & $59.75 d$ & $59.34 d$ \\
\hline Giza 429 & $45.00 \mathrm{c}$ & $52.00 \mathrm{~d}$ & $85.30 \mathrm{~b}$ & $70.40 \mathrm{e}$ & $38.65 \mathrm{~cd}$ & $36.42 \mathrm{~d}$ & $22.13 \mathrm{~g}$ & $22.25 \mathrm{~g}$ & $51.15 \mathrm{j}$ & $51.20 \mathrm{~g}$ \\
\hline Giza 843 & $45.00 \mathrm{c}$ & $47.25 \mathrm{e}$ & $80.75 \mathrm{c}$ & $79.10 \mathrm{~d}$ & $36.57 d$ & $37.52 \mathrm{~d}$ & $22.34 \mathrm{~g}$ & $22.447 \mathrm{fg}$ & $52.10 \mathrm{i}$ & $51.33 \mathrm{~g}$ \\
\hline F. test & $* *$ & $* *$ & $* *$ & $* *$ & $* *$ & $* *$ & $* *$ & $* *$ & $* *$ & ** \\
\hline
\end{tabular}

**: Significant at 0.01 level of probability. 
Generally, mean performance of the ten faba bean cultivars for earliness characters indicated that the new faba bean cultivars were earlier than the old faba bean ones during the two seasons. The two new cultivars, Wadi 1 and Nubaria 3 were the earliest ones, while, the two old cultivars, Giza 843 and Giza 3 were the latest ones in both seasons. Verma et al. (2015), Jalal et al. (2016) and Hamza and Khalifa (2017) recorded highly significant differences among faba bean cultivars for days to $50 \%$ flowering.

\section{Yield and its attributes}

Mean performance of yield and its attributes for the ten faba bean cultivars during the two seasons are given in Table 3 . Highly significant $(\mathrm{P}<0.01)$ differences were recorded among the ten faba bean cultivars for yield and its attributes during both seasons, indicating the presence of adequate genetic variability in the used genetic material. In this respect, highly significant differences among faba bean cultivars were recorded for plant height, number of branches / plant, pod length, number of pods/plant, number of seeds/pod, number of seeds/plant, 100-seed weight and seed yield/plant by Ahmed $\boldsymbol{e t}$ al. (2013), Sharifi (2014), Mitiku and Wolde (2015), Sharifi (2015), Tamene et al. (2015), Verma et al. (2015), Degife and Kiya (2016), Hamza (2017), Hamza and Khalifa (2017) and Hussein et al. (2017).

For plant height it is clear from Table 3 , that the faba bean cultivars Nubari $1(88.75,91.37$ $\mathrm{cm})$, Giza $40(95.00,98.75 \mathrm{~cm})$ and Giza 843 $(95.00,98.75 \mathrm{~cm})$ were the shortest ones among the evaluated faba bean cultivars during the two seasons, respectively. Therefore, these cultivars are considered as dwarf cultivars. On the other hand, the faba bean cultivars Giza 2 (126.27, $127.50 \mathrm{~cm})$ and Giza $429(118.85,117.60 \mathrm{~cm})$ were the tallest ones during the first and the second seasons, respectively. These results are in agreement with those reported by Bakry et al. (2011), who found that faba bean cultivars Nubari 1 and Giza 843 were had the shortest plants.

Mean performance of number of branches/ plant (Table 3) indicated that faba bean cultivars Giza 429 (4.65 and 4.82) and Misr 3 (4.07 and
4.07) exhibited the highest number of branches/ plant among the studied cultivars during the two seasons, respectively. Whereas, the cultivar Giza 843 (2.50) was the fewest and produced 2.50 branches during the first and the second seasons.

Concerning number of fruiting nodes/plant during the two seasons (Table 3 ). The results indicated that faba bean cultivars Giza 2 and Giza 429 (17.50, 14.50) and Nubaria 3 (16.00, 14.75) produced the greatest number of fruiting nodes/plant during the two seasons, respectively, revealing that these cultivars are promising for this trait. While, the two faba bean cultivars Nubria 1 (9.00, 9.25) and Wadi 1 (9.25, 9.25) produced the lowest number of fruiting nodes/plant during both seasons, respectively.

Results given in Table 3 indicate that the two cultivars Giza $40(10.75 \mathrm{~cm})$ and Nubaria 1 $(10.17 \mathrm{~cm})$ produced the longest pods in first season, and Nubaria $1(11.5 \mathrm{~cm})$ in the second one. Hereby, both cultivars are the promising ones and could be involved in faba bean breeding programs for improving pod length. Otherwise, the old faba bean cultivars Giza 429 $(8.25,8.25 \mathrm{~cm})$ and Giza $2(8.75,8.82 \mathrm{~cm})$ produced the shortest pods during the two seasons, respectively.

The maximum number of pods /node were recorded by Giza 2 (2.60, 2.32) followed by Sakha $4(2.00,2.65)$ in first and second seasons, respectively. On the other hand, the fewest number of pods/ node was recorded by Wadi 1 $(1.07,1.15)$ during the two seasons, respectively (Table 3).

In continuous as shown in Table 3, number of pods/plant showed that, faba bean cultivars Giza 2 (21.65, 20.62), Giza 40 (18.85, 18.00), Misr 3 (17.50, 17.25) as well as Nubaria 1 $(17.25,17.50)$ produced the greatest number of pods/plant during the two seasons, respectively. Whereas, cultivars Wadi $1(10.50,12.25)$ and Giza $3(12.32,12.25)$ produced the lowest number of pods/plant during the first and the second seasons, respectively.

As given in Table 3, the faba bean cultivars Nubaria 1 (5.17, 4.60), Giza $40(4.50,4.82)$ as well as Sakha $4(4.07,4.07)$ produced the greatest number of seeds/pod during both seasons, respectively. Whereas, faba bean cultivars Nubaria 3 (3.0, 3.0) and Giza 429 (3.0, 
3.0) produced the lowest number of seeds/ pod during the two seasons, respectively. Bakry et al. (2011) found that Nubaria 1 variety had the highest number of seeds/pod.

The maximum number of seeds/plant was recorded from Nubaria 1 (71.95) in the first season, Giza 40 (74.87) and Giza 2 (70.25) in the second one. While, the lowest number was registered from Wadi 1 (34.75) in first season as well as Giza 3 (41.00) in second season (Table 3 ). This result revealed that faba bean cultivars Nubaria 1, Giza 40 and Giza 2 cultivars has large seed size. Seed size is one of the important parameters for the choice of the cultivars by the growers.

Mean performance of 100 -seed weight (Table 3) indicated that the new faba bean cultivars Misr 3 (96.70, $97.45 \mathrm{~g}$ ), Sakha 4 $(92.65,94.02 \mathrm{~g})$ as well as Nubaria 1 (94.72, $91.70 \mathrm{~g}$ ) exhibited the heaviest 100 -seed weight during both seasons, respectively. On the other hand, the cultivars Nubaria 3 (58.60, $62.55 \mathrm{~g}$ ) and Giza 2 (60.00, 60.22 g) exhibited the lightest 100- seed weight during the two seasons, respectively.

Mean performance of seed yield/plant indicated that faba bean cultivars Nubaria $1(70.42,57.10$ $\mathrm{g})$, Misr $3(43.20,41.87 \mathrm{~g})$ as well as Giza 40 $(40.30,52.32 \mathrm{~g})$ gave the highest productivity during the first and the second seasons, respectively. Whereas, the cultivar Nubaria 3 $(27.30,28.05 \mathrm{~g})$ as well as Giza 3 (28.02, $30.57 \mathrm{~g}$ ) gave the lowest productivity during the two seasons, respectively. These results are in agreement with the finding of Bakry et al. (2011) who reported that Nubaria 1 variety was the highest in seed yield / plant compared to the other varieties.

\section{Quality characteristics}

Results given in Table 3 clearly indicate highly significant differences among faba bean cultivars for both protein and carbohydrate contents, suggesting that, faba bean cultivars were genetically different in genes controlling quality characters. Similar trend of results were obtained by Awadalla et al. (2013) and Verma et al. (2015). Results revealed that the highest value of protein and carbohydrate contents were registered by Sakha $4(27.55 \%$ and $28.26 \%$ protein) and (65.5\% and $65.15 \%$ carbohydrate) during first and second seasons, respectively, followed by Misr 3 (24.82\% protein) in the first season, Giza 40 (25.08\% protein) in the second season, respectively, Misr $3(63.45 \%$ and $63.22 \%$ Carbohydrate) during the two seasons, respectively. While, the lowest values of protein and carbohydrate contents were registered by Giza 429 (22.13\% and $22.25 \%$ protein) as well as $(51.15 \%$ and $51.20 \%$ carbohydrate) during the two seasons, respectively. Awadalla et al. (2013) found that Sakha 4 variety had the highest carbohydrate content rather than the other varieties.

\section{Correlation Coefficient Analysis}

Correlation coefficient was used to determine the most effective characters which played an important role in seed yield/plant. As given in Table 4, seed yield/plant was positively and significantly correlated with each of pod length, number of pods/plant, number of seeds/pod, number of seeds/plant as well as 100-seed weight during the two seasons. In this respect, positive and significant association was recorded between seed yield with each of number of pods/plant, number of seeds/pod and 100- seed weight by many others (Ulukran et al., 2003; Ahmed et al., 2013; Sharifi, 2014; Verma et al., 2015; Jalal et al., 2016; Hamza, 2017; Hamza and Khalifa, 2017; Kumar et al., 2017; Tekalign et al., 2017). Also, Mitiku and Wolde (2015) showed that, number of seeds/pod with seed yield/plant was positively and significantly correlated. Otherwise, correlation between seed yield/plant and each of plant height as well as number of fruiting nodes/plant were negative and significant during the two seasons, suggest that selection in negative direction for these characters will also increase faba bean yield. Insignificant correlation was recorded between seed yield/plant with days to first flower, days to $50 \%$ flowering as well as days to fruiting during the two seasons. These results are supported by the finding of Tadesse et al. (2011), Ahmed et al. (2013) and Tekalign et al. (2017) who observed insignificant association between days to flowering and seed yield. Also Jalal et al. (2016) showed that, days to $50 \%$ flowering with seed yield was insignificantly correlated during the two seasons. 
Table 4. Correlation coefficient analysis among earliness, yield, its attributes and quality characters during the two seasons of 2014 / 2015 and 2015 / 2016

\begin{tabular}{|c|c|c|c|c|c|c|c|c|c|c|c|c|c|c|c|}
\hline Character & Dff & D 50\%F & Df & $\mathbf{P h}$ & $\mathbf{N b}$ & Nfnp & Pol & Npon & Npop & Nsepo & Nsep & 100-Swt & $\mathrm{PC}(\%)$ & $\mathrm{CC}(\%)$ & Sy \\
\hline \multicolumn{16}{|c|}{$2014 / 2015$} \\
\hline Dff & & $0.921 * *$ & $0.883 * *$ & -0.153 & 0.051 & 0.154 & 0.128 & 0.207 & 0.329* & 0.006 & $0.332 *$ & -0.094 & -0.284 & -0.060 & 0.191 \\
\hline D 50\% F & & & $0.861 * *$ & -0.171 & -0.017 & 0.098 & 0.035 & 0.114 & $0.420 * *$ & -0.050 & 0.278 & -0.0719 & $-0.354 *$ & -0.171 & 0.122 \\
\hline Df & & & & -0.007 & 0.098 & $0.431 * *$ & 0.074 & 0.278 & $0.450 * *$ & -0.135 & $0.332 *$ & $-0.366^{*}$ & $-0.438 * *$ & -0.234 & 0.029 \\
\hline $\mathbf{P h}$ & & & & & $0.441 * *$ & $0.649 * *$ & $-0.577 * *$ & $0.416 * *$ & 0.087 & $-0.586 * *$ & $-0.346 *$ & $-0.333 *$ & -0.081 & -0.189 & $-0.525 * *$ \\
\hline $\mathbf{N b}$ & & & & & & $0.301 *$ & $-0.315^{*}$ & 0.015 & 0.101 & -0.214 & -0.19 & 0.182 & -0.124 & -0.058 & -0.084 \\
\hline Nfnp & & & & & & & $-0.323 *$ & $0.442 * *$ & 0.255 & $-0.351 *$ & 0.024 & $-0.611 * *$ & -0.232 & -0.268 & $-0.365^{*}$ \\
\hline Pol & & & & & & & & -0.074 & 0.083 & $0.572 * *$ & $0.337 *$ & 0.086 & $0.358 *$ & $0.482 * *$ & $\mathbf{0 . 3 3 5 *}$ \\
\hline Npon & & & & & & & & & 0.225 & -0.114 & 0.168 & $-0.392 *$ & 0.109 & 0.022 & -0.106 \\
\hline Npop & & & & & & & & & & 0.174 & $0.643 * *$ & -0.130 & -0.2241 & -0.103 & $0.372 *$ \\
\hline Nspo & & & & & & & & & & & $0.620 * *$ & $0.314 *$ & 0.287 & $0.324 *$ & $0.666^{* * *}$ \\
\hline Nsp & & & & & & & & & & & & -0.018 & -0.134 & -0.064 & $0.798 * *$ \\
\hline 100-Swt & & & & & & & & & & & & & $0.304 *$ & $0.364 *$ & $0.514 * *$ \\
\hline $\mathrm{PC}(\%)$ & & & & & & & & & & & & & & $0.903 * *$ & 0.041 \\
\hline $\mathrm{CC}(\%)$ & & & & & & & & & & & & & & & 0.131 \\
\hline \multicolumn{16}{|c|}{$2015 / 2016$} \\
\hline Dff & & $0.947 * *$ & $0.890 * *$ & -0.021 & -0.033 & $0.353 *$ & -0.227 & $0.326 *$ & 0.225 & -0.019 & 0.245 & -0.235 & $-\mathbf{0 . 1 3 3}$ & -0.081 & 0.097 \\
\hline D 50\% F & & & $0.888 * *$ & -0.023 & -0.089 & $0.348 *$ & -0.269 & $0.311 *$ & 0.273 & -0.010 & 0.271 & -0.273 & -0.160 & -0.098 & 0.091 \\
\hline Df & & & & 0.062 & 0.049 & $0.471 * *$ & $-0.353 *$ & 0.117 & 0.257 & -0.095 & $0.429 * *$ & $-0.520 * *$ & $-0.359 *$ & $-0.310 *$ & 0.058 \\
\hline $\mathbf{P h}$ & & & & & $0.399 *$ & $0.540 * *$ & $-0.356^{*}$ & $0.393 *$ & 0.141 & $-0.476 * * *$ & $=-\mathbf{0 . 0 2 5}$ & $-0.340 *$ & -0.079 & -0.043 & $-0.398^{*}$ \\
\hline $\mathrm{Nb}$ & & & & & & 0.155 & -0.021 & 0.082 & -0.050 & -0.186 & -0.024 & -0.045 & -0.154 & -0.025 & -0.104 \\
\hline Nfnp & & & & & & & $-0.522 * *$ & 0.287 & 0.046 & -0.291 & 0.169 & $-0.683 * *$ & 0.095 & 0.025 & $-0.429 * *$ \\
\hline Pol & & & & & & & & -0.095 & 0.040 & $0.478 * *$ & 0.057 & $0.451^{* * *}$ & 0.297 & 0.280 & $0.459 * *$ \\
\hline Npon & & & & & & & & & 0.137 & -0.091 & -0.129 & 0.051 & $0.314 *$ & 0.333* & -0.100 \\
\hline Npop & & & & & & & & & & 0.213 & $0.662 * *$ & -0.176 & -0.196 & -0.093 & $0.545 * *$ \\
\hline Nspo & & & & & & & & & & & $0.404 * *$ & $0.335^{*}$ & $0.386^{*}$ & 0.294 & $0.716^{* * *}$ \\
\hline Nsp & & & & & & & & & & & & $-0.461^{* * *}$ & -0.210 & -0.263 & $0.663^{* * *}$ \\
\hline 100-Swt & & & & & & & & & & & & & $0.427 * *$ & $0.475 * *$ & $0.306^{*}$ \\
\hline PC (\%) & & & & & & & & & & & & & & $0.865 * *$ & 0.103 \\
\hline $\mathrm{CC}(\%)$ & & & & & & & & & & & & & & & 0.086 \\
\hline
\end{tabular}

$*$, **=significant at 0.05 and 0.01 levels of probability, respectively.

Dff = Days to first flower (day), D 50\% F = Days to $50 \%$ flowering (day), Df = Days to fruiting $($ day $), \mathrm{Ph}=\mathrm{Plant}$ height $(\mathrm{cm}), \mathrm{Nb}=$ Number of branches/plant, Nfnp $=$ Number of fruiting nodes/plant, Pol $=$ Pod length $(\mathrm{cm}), \mathrm{Npon}=\mathrm{Number}$ of pods $/$ node, Npop $=$ Number of pods/plant, Nspo $=$ Number of seeds/pod, Nsp = Number of seeds/plant, $100-$ Swt $=100-$ seed weight (g.), PC $(\%)=$ Protein content $(\%)$, CC $(\%)=$ Carbohydrate content $(\%)$ and Sy $=$ Seed yield $/$ plant $(\mathrm{g}$.$) .$

Furthermore, correlation of seed yield/plant with protein and carbohydrate contents was insignificant during the two seasons. Similar results were obtained by Verma et al. (2015) for protein content.

\section{Path Coefficient Analysis}

Path coefficient analysis helps to estimate the influence of each variable upon the resultant variable by partitioning the correlation coefficients. Seed yield/plant was selected as resultant variable and plant height, number of fruiting nodes/plant, pod length, number of pods/plant, number of seeds/pod, number of seeds/plant and 100-seed weight as causal variable. The results of path coefficient analysis are illustrated in Table 5.

The highest positive direct effects on faba bean seed yield were exhibited by number of seeds/plant $(0.931,0.873)$ followed by 100 -seed weight $(0.492,0.594)$ during the two seasons, respectively. Hereby, number of seeds/plant followed by 100-seed weight may be used as direct selection criteria in faba bean breeding program designed to increase seed yield. Similarly, number of seeds/plant showed positive indirect effects via number of fruiting nodes/plant, pod length, number of pods/plant and number of seeds/pod during the two seasons. Also, the indirect effects of 100-seed weight via pod length and number of seeds/pod were found to be positive during the two seasons, suggested that indirect selection for number of seeds/plant and 100-seed may increase seed yield. In this respect, positive direct effect was recorded for 100-seed weight on seed yield /plant by Tadesse et al. (2011), Sharifi (2015), Verma et al. (2015), Hamza and Khalifa (2017), Kumar et al. (2017) and Tekalign et al. (2017). 
Qabil, et al.

Table 5. Path coefficient analysis showing direct and indirect effects of different attributes on seed yield/plant during the two seasons of 2014/2015 and 2015/2016

\begin{tabular}{|c|c|c|c|c|c|c|}
\hline Character & $\begin{array}{l}\text { Plant } \\
\text { height } \\
\text { (cm) }\end{array}$ & $\begin{array}{c}\text { Number of } \\
\text { fruiting } \\
\text { nodes/plant }\end{array}$ & $\begin{array}{l}\text { Pod } \\
\text { length } \\
\text { (cm) }\end{array}$ & $\begin{array}{c}\text { Number } \\
\text { of pods/ } \\
\text { plant }\end{array}$ & $\begin{array}{cc}\text { Number } & \text { Number } \\
\text { of seeds/ of seeds/ } \\
\text { pod plant }\end{array}$ & $\begin{array}{l}\text { 100-seed Correlation } \\
\text { weight with yield } \\
\text { (g.) }\end{array}$ \\
\hline
\end{tabular}

\begin{tabular}{|c|c|c|c|c|c|c|c|c|}
\hline \multicolumn{9}{|c|}{ Direct (Diagonal) and indirect effect of yield attributes on yield $(2014 / 2015)$} \\
\hline Plant height (cm) & -0.044 & -0.037 & 0.003 & -0.011 & 0.051 & -0.322 & -0.164 & -0.525 \\
\hline Number of fruiting nodes/ plant & -0.029 & -0.057 & 0.002 & -0.033 & 0.030 & 0.022 & -0.301 & -0.365 \\
\hline Pod length (cm) & 0.026 & 0.018 & -0.005 & -0.011 & -0.049 & 0.314 & 0.042 & 0.335 \\
\hline Number of pods/plant & -0.004 & -0.015 & -0.001 & -0.129 & -0.015 & 0.599 & -0.064 & 0.372 \\
\hline Number of seeds/pod & 0.026 & 0.020 & -0.003 & -0.022 & -0.086 & 0.577 & 0.154 & 0.666 \\
\hline Number of seeds/plant & 0.015 & -0.001 & -0.002 & -0.083 & -0.054 & 0.931 & -0.009 & 0.798 \\
\hline 100 - seed weight (g.) & 0.015 & 0.035 & -0.001 & 0.017 & -0.027 & -0.017 & 0.492 & 0.514 \\
\hline \multicolumn{9}{|c|}{ Direct (Diagonal) and indirect effect of yield attributes on yield $(2015 / 2016)$} \\
\hline Plant height (cm) & -0.097 & -0.048 & -0.010 & 0.011 & -0.030 & -0.022 & -0.202 & -0.398 \\
\hline Number of fruiting nodes/ plant & -0.052 & $-\mathbf{0 . 0 8 9}$ & -0.014 & 0.003 & -0.018 & 0.148 & -0.406 & -0.429 \\
\hline Pod length (cm) & 0.034 & 0.047 & 0.027 & 0.003 & 0.030 & 0.050 & 0.268 & 0.459 \\
\hline Number of pods/plant & -0.014 & -0.004 & 0.001 & 0.075 & 0.014 & 0.578 & -0.105 & 0.545 \\
\hline Number of seeds/pod & 0.046 & 0.026 & 0.013 & 0.016 & 0.063 & 0.353 & 0.199 & 0.716 \\
\hline Number of seeds/plant & 0.002 & -0.015 & 0.002 & 0.050 & 0.026 & 0.873 & -0.274 & 0.663 \\
\hline 100 - seed weight (g.) & 0.033 & 0.061 & 0.012 & -0.013 & 0.021 & -0.402 & 0.594 & 0.306 \\
\hline
\end{tabular}

The direct effect of pod length, number of pods/plant and number of seeds/pod on seed yield was positive in the second season. So, these characters could be considered as a selection criteria for improving faba bean seed yield. These results also agree with those of Tadesse et al. (2011), Sharifi (2014), Sharifi (2015), Verma et al. (2015) and Kumar et al. (2017) they found that pod length, number of pods/plant and number of seeds/pod had positive direct effect on seed yield. Meantime, pod length had positive indirect effect via plant height and number of fruiting nodes/plan in the first season as well as number of pods/plant, number of seeds/pod, number of seeds/plant and 100 -seed weight in the second one. Also, indirect effects of number of pods/plant via 100seed weigh in the first season as well as plant height, number of fruiting nodes/plan, pod length, number of seeds/pod and number of seeds/plant in the second season were positive.
Number of seeds/pod exhibited positive indirect effects via plant height, number of fruiting nodes/plan in the first season as well as pod length, number of pods/plant, number of seeds/plant and 100-seed weight in the second one. While, direct effect of plant height, number of fruiting nodes/plant during the two seasons as well as pod length, number of pods/plant and number of seeds/pod in the first season on seed yield was negative. Meantime, plant height had negative indirect effect via number of fruiting nodes/plant and number of pods/plant during the two seasons.

\section{Molecular Markers RAPD-PCR}

In the present study, five primer of RAPD were selected to identify genetic diversity among the ten faba bean cultivars. These primers produce multiple bands, which ranged between 4 bands for primer D13 to 9 bands for primer C06. The total number of bands were 32 , 
which 21 of them were polymorphic with $65.6 \%$ polymorphism. The highest level of polymorphism could be observed in primer C19 which showed $75 \%$, while the lowest polymorphism valued $50 \%$ in primer D13 (Table 6 and Fig. 1).

RAPD analysis can produce four positive markers was observed in Giza 3 faba bean cultivar, which present in the two primers (C06 and C19) at different molecular weight (MW) produce 2 bands, $1850 \mathrm{bp}$ and $1200 \mathrm{bp}$ in primer C06 and the other two at mw 2850 bp and1850 bp in primer $\mathrm{C} 19$. Giza 40 which present two positive markers one of them in primer B09 in MW $580 \mathrm{bp}$, while the other in MW $1210 \mathrm{bp}$ at primer C19. Whereas, Giza 429 recorded one band negative at $450 \mathrm{bp}$ in primer C19. Giza 843 has one band positive marker at $1020 \mathrm{bp}$ in primer C19. Yahia et al. (2014) used SSR and RAPD markers to evaluate the genetic diversity of 13 Tunisian faba bean genotypes and showed that the polymorphic fragments percentages were 100 and $60.63 \%$ for SSR and RAPD markers, respectively.

\section{Combined Analysis for Seven Faba bean Cultivars}

Similarity index and dendrogram across the ten faba been cultivars under investigation based on RAPD analysis are shown in Table 7 and Fig. 2 , respectively. The comparison revealed that the highest genetic similarity was recorded between Sakha 4 and Wadi 1 (0 .970), followed by Misr 3 and Nubaria 3 (0.919). The lowest relationship was recorded for cultivars Giza 3 and Giza 429 (0.619). The dendrogram (Fig. 2) resulted in two main clusters. One of them involved the cultivars Giza 3 and Giza 40, while the second cluster involved the rest cultivars. The second cluster was divided into two subclusters, one included Misr 3 and Nubaria 3, while the second cluster involved Sakha 4, Wadi 1, Nubaria 1, Giza 429, Giza 2 and Giza 843.

Table 6. Levels of polymorphism by the five RAPD primers a cross ten faba bean cultivars

\begin{tabular}{|c|c|c|c|c|c|c|c|c|}
\hline \multirow{2}{*}{$\begin{array}{c}\text { Primer } \\
\text { name }\end{array}$} & \multirow[t]{2}{*}{ MW(bp) } & \multirow{2}{*}{$\begin{array}{c}\text { Number of } \\
\text { Monomorphic } \\
\text { bands (nmb) }\end{array}$} & \multirow{2}{*}{$\begin{array}{l}\text { Number of } \\
\text { Polymorphic } \\
\text { bands (npb) }\end{array}$} & \multirow[t]{2}{*}{ NB } & \multirow[t]{2}{*}{$\mathbf{P}(\%)$} & \multirow[t]{2}{*}{ Genotypes } & \multicolumn{2}{|c|}{ MM } \\
\hline & & & & & & & $\overline{\text { PM }}$ & NM \\
\hline B09 & $2600: 580$ & 2 & 3 & 5 & 60 & Giza 40 & 580 & \\
\hline \multirow[t]{2}{*}{$\mathrm{CO6}$} & $1850: 310$ & 3 & 6 & 9 & 66.7 & Giza 3 & 1850 & \\
\hline & & & & & & & 1200 & \\
\hline $\mathrm{CO8}$ & $2800: 675$ & 2 & 4 & 6 & 66.7 & & & \\
\hline \multirow[t]{5}{*}{ C19 } & $2850: 450$ & 2 & 6 & 8 & 75 & Giza 3 & 2850 & \\
\hline & & & & & & & 1850 & \\
\hline & & & & & & Giza 40 & 1210 & \\
\hline & & & & & & Giza 843 & 1020 & \\
\hline & & & & & & Giza 429 & & 450 \\
\hline D13 & $1220: 450$ & 2 & 2 & 4 & 50 & & & \\
\hline Total & & 11 & 21 & 32 & 65.6 & & & \\
\hline \multicolumn{9}{|l|}{ Where: } \\
\hline NB, & \multirow{2}{*}{\multicolumn{2}{|c|}{$\begin{array}{c}\text { Number of bands } \\
\text { Positive marker }\end{array}$}} & MM, & \multirow{2}{*}{\multicolumn{2}{|c|}{$\begin{array}{c}\text { Molecular marker } \\
\text { Negative marker }\end{array}$}} & $\mathbf{P}(\%)$, & \multicolumn{2}{|c|}{ Polymorphism (\% } \\
\hline PM, & & & NM, & & & & & \\
\hline MW, & Molecu & weight & & & & & & \\
\hline
\end{tabular}



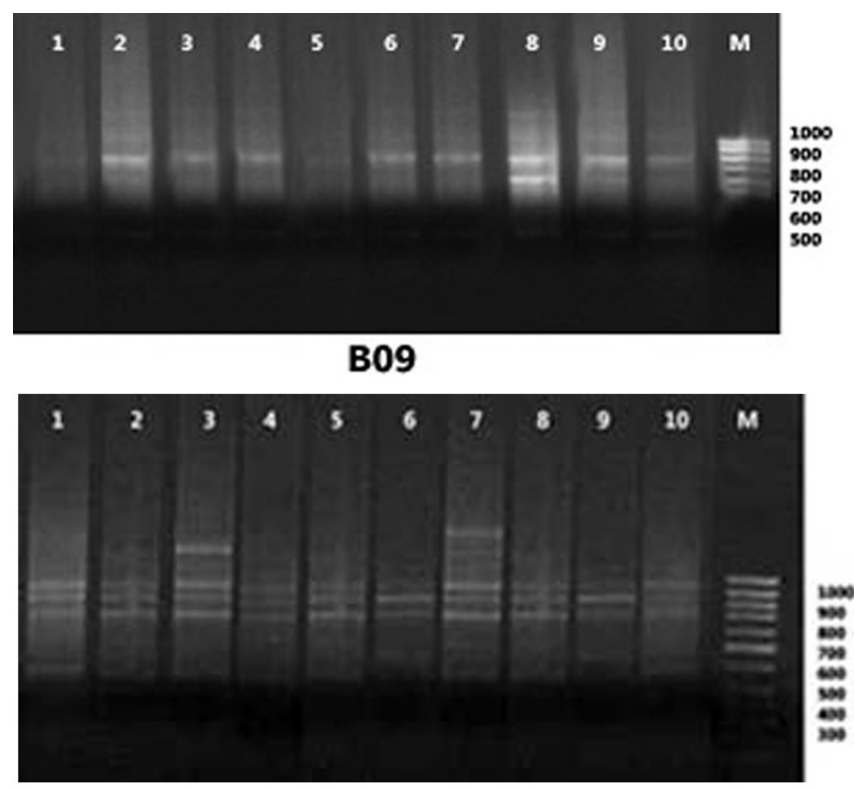

C06

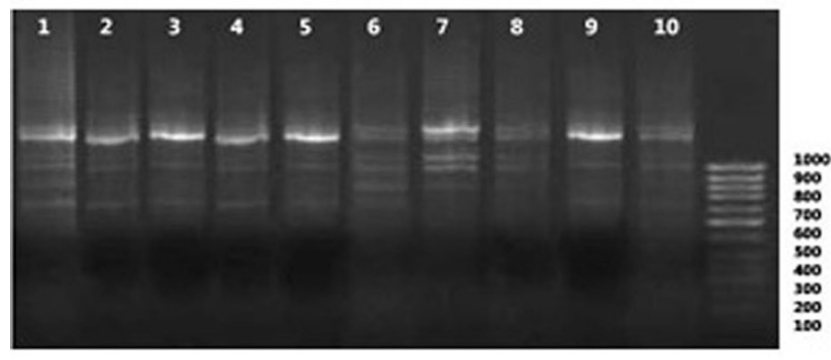

C08
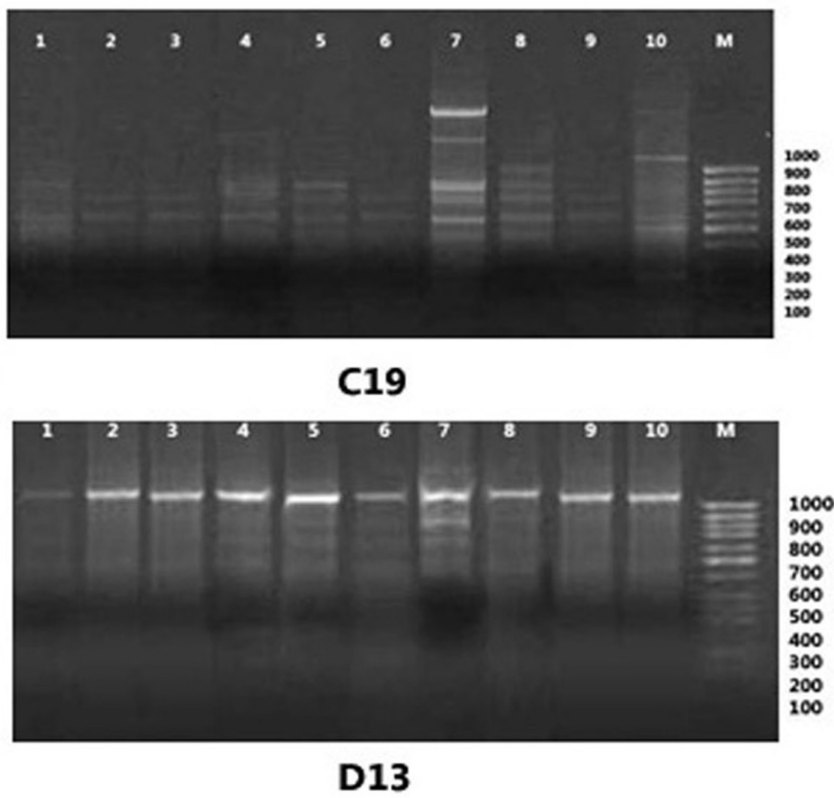

Fig. 1. RAPD banding patterns amplified with 5 primers a cross ten faba bean cultivars 
Table 7. Similarity matrix among the ten faba bean cultivars using RAPD analysis

\begin{tabular}{lccccccccc}
\hline Cultivar & Misr 3 & Sakha 4 & Wadi 1 & Nubaria 1 & Nubaria 3 & Giza 2 & Giza 3 & Giza 40 Giza 429 \\
\hline Sakha 4 & 0.778 & & & & & & & \\
Wadi 1 & 0.757 & 0.970 & & & & & & \\
Nubaria 1 & 0.811 & 0.909 & 0.882 & & & & & & \\
Nubaria 3 & 0.919 & 0.848 & 0.842 & 0.882 & & & & & \\
Giza 2 & 0.872 & 0.800 & 0.778 & 0.833 & 0.778 & & & & \\
Giza 3 & 0.809 & 0.651 & 0.682 & 0.682 & 0.727 & 0.783 & & & \\
Giza 40 & 0.744 & 0.769 & 0.811 & 0.750 & 0.700 & 0.762 & 0.800 & & \\
Giza 429 & 0.686 & 0.902 & 0.875 & 0.875 & 0.750 & 0.824 & 0.619 & 0.737 & \\
Giza 843 & 0.789 & 0.882 & 0.857 & 0.800 & 0.800 & 0.865 & 0.711 & 0.780 & 0.848 \\
\hline
\end{tabular}

Rescaled Distance Cluster Combine

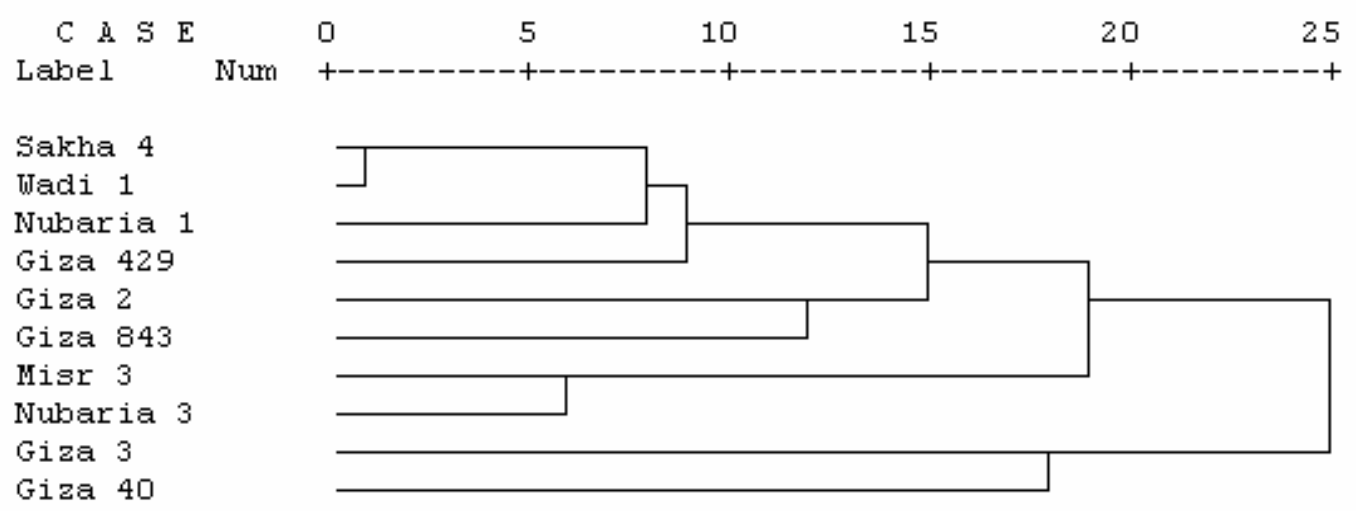

Fig. 2. Dendrogram of the genetic distances among the ten faba bean cultivars based on RAPD analysis

\section{REFERENCES}

Achtak, H.A., M.A. Oukablio and S. Santoni (2009). Microsatellite markers as reliable tools for fig cultivar identification. J. Ame. Soc. Hort. Sci., 134: 624 - 631.

Ahmed, A.M.O., H.A. Abdel Aziz and B.G. Mohamed (2013). Correlation between seed yield and yield components in faba bean (Vicia faba L.). Adv. Environ. Biol., 7(1): $82-85$

Awadalla, S.S., F.E. Abdallah and N.R. El-Mashaly (2013). Influence of some varieties on the main insect pests attacking faba bean plants.
J. Plant Prot. and Path., Mansoura Univ., 4 (6): 581-589.

Baheer-Salimia, R., R.M. Awad and J. Ward (2012). Assessment of biodiversity based on molecular markers and morphological traits among westbank, Palestine fig genotypes (Ficus caria L.). Ame. J. Plant Sci., 3: 12411251.

Bakry, B.A., T.A. Elewa, M.F. El-Karamany, M.S. Zeidan and M. Tawfik (2011). Effect of row spacing on yield and its components of some faba bean varieties under newly reclaimed sandy soil condition. J. Agric. Sci., 7 (1): 68-72. 
Degife, A.Z. and A.T. Kiya (2016). Evaluation of faba bean (Vicia faba L.) varieties for yield at gircha research center, gamo gofa zone, southern Ethiopia. Scholarly J. Agric. Sci., 6 (6): 169-176.

Dewy, D.R. and K.H. Lu (1959). A correlation and path-coefficient analysis of components of crested wheat grass seed production. Agron. J., 51: 515-518.

Duncan, D.B. (1955). Multiple Range and Multiple F-test. Biomet., 11 : 1- 42.

El-Hady, M., M.A. Omar, S.M. Nas, R.A. Ali and M.S. Esso (1998). Gene action of seed yield and some yield components in $F_{1}$ and $\mathrm{F}_{2}$ crosses among five faba bean (Vicia faba L.) genotypes. Bull., Fac. Agric., Cairo, Univ., 49 (3): 369-388.

FAO (2018). Production Year Book, 54, FAO, Rome.

Haciseferogullari, H., I. Geaer, Y. Bahtiyarca and H.O. Mengs (2003). Determination of some chemical and physical properties of sokiz faba bean (Vicia faba L.). J. Food Eng., 60 (4): 476-479.

Hamza, F.E.A. (2017). Performance assessment, genetic variability, heritability, genetic advance and correlation coefficient analysis for yield and some agro -morphological traits in faba bean (Vicia faba L.) genotypes in the northern state, Sudan. Int. J. Curr. Microbiol. App. Sci., 6 (11): 1206-1214.

Hamza, F.E.A. and G.E. Khalifa (2017). The correlation and path coefficient analysis for yield and some yield components of faba bean (Vicia faba L.) genotypes in Northern Sudan. Nile J. Agric. Sci., 2 (1): 52-63.

Hussein, M., A. Embiale, A. Husen, I.M. Aref and M. Iqbal (2017). Salinity-induced modulation of plant growth and photosynthetic parameters in faba bean (Vicia faba L.) cultivars. Pak. J. Bot., 49 (3): 867-877.

Jalal, O.A., R.A. Anwar and A.M. Ribwar (2016). Comparative on yield and its components performance and correlation in some broad bean (Vicia faba L.) genotypes at Bakrajo, Sulaimani. Ame-Eurasian J. Agric. and Environ. Sci., 16 (3): 635-640.
Kocsis, M.L., P. Jaromi and P. Kozma (2005). Genetic diversity among twelve grape cultivars indigenous to the Carpathian basin revealed by RAPD markers. Vitis, 44:87-91.

Kumar, P., R.R. Das, S.K. Bishnoi and V. Sharma (2017). Inter-correlation and path analysis in faba bean (Vicia faba L.). Electronic J. Plant Breed., 8 (1): 395-397.

Lindemann, C. and R. Glover (2003). Nitrogen fixation by legumes. Coll. Agric., Consumer and Environ. Sci., New Mexico State Univ., Guide A-129.

Mitiku, A. and M. Wolde (2015). Effect of faba bean (Vicia faba L.) varieties on yield attributes at Sinana and Agarfa districts of bale zone, southeastern Ethiopia. Jordan J. Biol. Sci., 8: 281-286.

Sambrook, J., E. Fritch and T. Maniatis (1989). Molecular Cloning: A Laboratory Manual, $2^{\text {nd }}$ Ed, Section E.5. Cold Spring Harbor Laboratory Press, Cold Spring Harbor Laboratory New York.

Sharifi, P. (2014). Correlation and path coefficient analysis of yield and yield component in some of broad bean (Vicia faba L.) genotypes. Genetika, 46 (3): 905 - 914.

Sharifi, P. (2015). Genetic variation for seed yield and some of agro-morphological traits in faba bean (Vicia faba L.) genotypes. Acta Agric. Slovenica, 105 (1): 73-83.

Tadesse, T., M. Fikere, T. Legesse and A. Parven (2011). Correlation and path coefficient analysis of yield and its components in faba bean (Vicia faba L.) germplasm. Int. J. Biodvers. Conserv, 3(8): 376-382.

Tekalign, A., J. Sibiya1 and J. Derera (2017). Heterosis and path analysis for grain yield and chocolate spot disease resistance in faba bean (Vicia faba L.). Aust. J. Crop Sci., 11(10):1244-1253.

Tahir, N.A. (2015). Identification of genetic variation in some faba bean (Vicia faba L.) genotypes grown in Iraq estimated with RAPD and SDS-PAGE of seed proteins, Indian J. Biotechnol., 14: 351-356.

Tamene, T., K. Gemechu and M. Hussein (2015). Genetic progresses from over three 
decades of faba bean (Vicia faba L.) breeding in Ethiopia. Aust. J. Crop. Sci., 9:41-48.

Ulukran, H., M. Gulerand and S. Keski (2003). A path coefficient analysis, some yield and yield components in faba bean (Vicia faba L.) genotypes. Pak. J. Biol. Sci., 6 (23): 1951- 1955.

Verma, R.K., C.B. Yadav and S.C. Gautam (2015). Germplasm evaluation and genetic divergence analysis in faba bean (Vicia faba L.). J. Agric. Search, 2 (2): 112-118.
Wang, H.F., X. Zong, J.P. Guan, T. Yang, X. L. Sun and Y. Ma (2012). Genetic diversity and relationship of global faba bean (Vicia faba L.) germplasm revealed by ISSR markers. Theoretical and Appl. Genet., 124: 789-797.

Yahia, Y., H. Hannachi and A. Ferchichi (2014). Genetic diversity of (Vicia faba L.) based on random amplified polymorphic DNA and simple sequence repeat marker. Acta Botanica Gallica: Botany Letters, 161 (2): 151-158.

\section{تقييم بعض الأصناف الحديثة والقديمة من الفول البلاى لصفات التبكير، المحصول ومساهماته والجودة نجلاء قبيل ' ـ أحمد جمال عبد الحميد هلالَ - رشا يوسف سيد عبد الخالق"$$
\text { ا ـقسم المحاصيل- كلية الزر اعة- جامعة الزقازيق- مصر }
$$

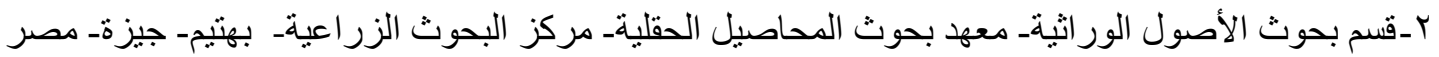$$
\text { rـ قسم بحوث تكنولوجيا البذور ـ معهد بحوث المحاصيل الحقلية ـ مركز البحوث الزر اعية ـ جيزةـ مصر }
$$

أجريت هذه الدراسة بمحطة البحوث الزر اعية ببهتيم بقسم بحوث الأصول الور اثيةـ مركز البحوث الزراعية، خلال

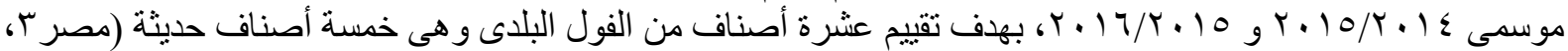

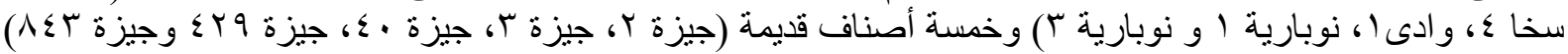

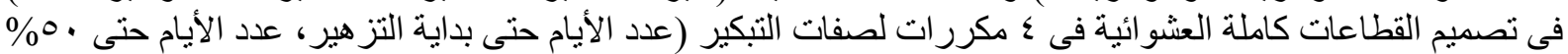

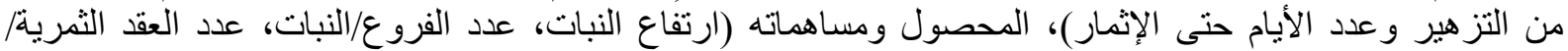

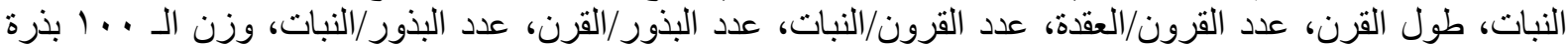

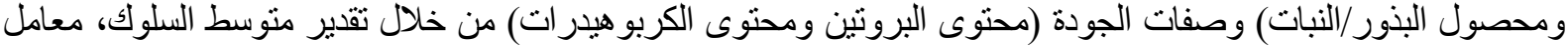

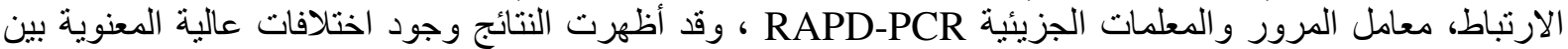

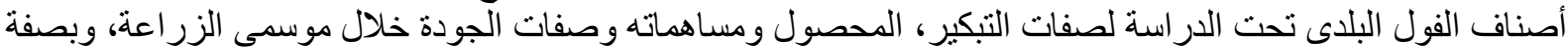

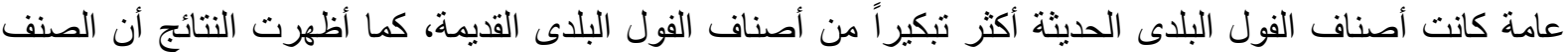

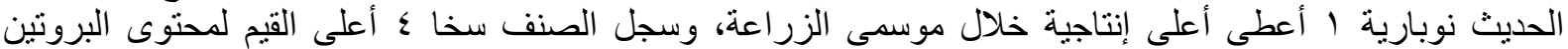

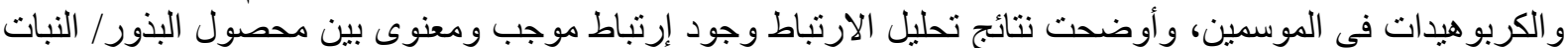

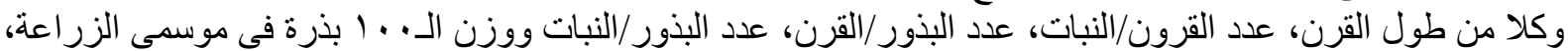

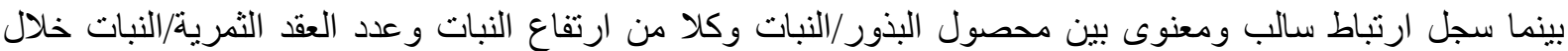

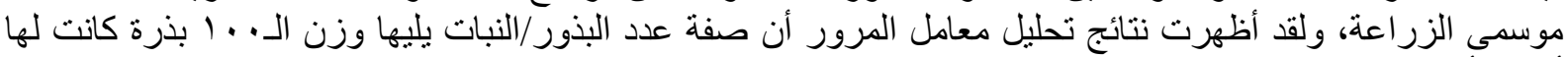

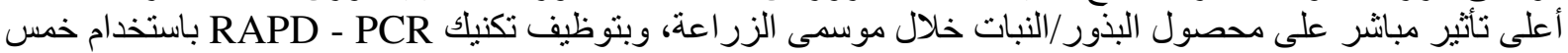

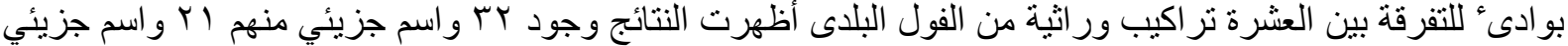

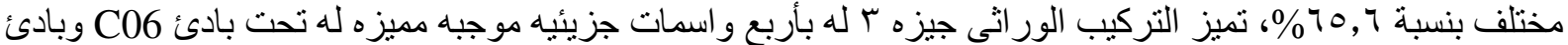

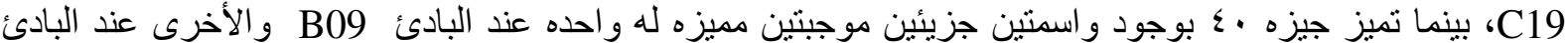

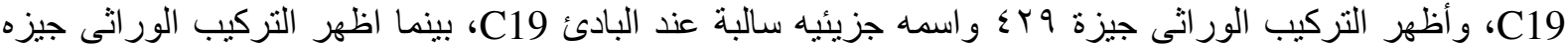

